\title{
Talajlazító mezőgazdasági vontatmány összeszerelési folyamatának fejlesztése
}

\section{Product assembly process improvement of agricultural cultivator trailers}

\author{
L. PuszTAI, B. Kocsi \\ University of Debrecen, pusztai.laszlo@inf.unideb.hu \\ University of Debrecen, kocsi.balazs@inf.unideb.hu
}

\begin{abstract}
Absztrakt. Tanulmányunk célja a kkv-k termelési hatékonyságának növelése volt költséghatékony folyamatfejlesztő eszközök segítségével. A vállalatok életében fontos szerepet játszanak a folyamatok, ugyanis az optimális folyamatlefutás kulcstényező a hatékony múködéshez. Annak érdekében, hogy megtartsuk, illetve növeljük a versenyelönyünket a konkurenciával szemben, folyamatainkat rendszeresen felül kell vizsgálni, és amennyiben szükséges, fejleszteni kell. A fejlesztéshez felhasználhatunk humán és fizikai tőkét egyaránt. Jelen tanulmányunkban bemutatjuk egy debreceni kisvállalkozás összeszerelési folyamatának fejlesztését. Folyamatmodellezés és adatgyüjtési technikák alkalmazásával megpróbálunk eljutni olyan javítóintézkedések meghozataláig, amellyel a teljes átfutási időben közel 50\%-os csökkenést tudunk elérni. A hibaokok feltárására és rangsorolására hibamód és hatáselemzést és az 5 miért módszert alkalmazzuk.
\end{abstract}

Abstract. The aim of our paper is to increase production efficiency of a small and medium sized enterprise by applying cost-effective process development tools. The existence of the firms depends on their business processes, because optimally-organised process is a key in the run of business (business run) in a productive way. In order to keep and grow the competitive edge with the competitions, firms must supervise their processes with constant frequency, and if it is needed, procedures must be developed. In this case, company can resort to both human and physical resources. Our experiment focused on the development of an assembly process at a small sized enterprise. Applying process modelling techniques, and diagnostic procedures, and also data gathering methods we try to get to define corrective actions, with which the whole lead time can be reduced by 50\%. For investigate and rank waste we use failure mode and effects analysis and 5 whys methods.

\section{Bevezetés}

Az elmúlt években a világ globalizálódása miatt egyre nagyobb verseny figyelhető meg a világ vállalatai között. Ez a vevői igények változását vonja maga után, így a versenyképesség fenntartásához a minőség-költség-szállítás horizontokon minél jobban kell teljesíteni a vállalatnak. A vizsgálatunk célja, hogy egy termelést végző vállalatnál hogyan lehet fejleszteni a folyamatot, hogy a teljes átfutási idő jelentősen csökkenjen. 


\section{Szakirodalmi áttekintés}

\section{Folyamatmodellezés}

Folyamatokkal az ember mindennapos tevékenységei során is találkozhat. Folyamatnak nevezzük azoknak a tevékenységeknek az összességét, melynek során adott cél elérése érdekében végzünk, erőforrást használunk el rá. A folyamat általános modellje egy bemenetből, tevékenységek sorozatából és kimenetből áll [1].

Modell alatt a valóság egyszerűsített, lekicsinyített vagy éppen felnagyított mását értjük [2]. Egy folyamat modellezésének hatékony módja a grafikus ábrázolás: számos grafikai folyamatábrázoló technikát ismer a mai szakirodalom, ezek közül az eseményvezérelt folyamatlánc diagramot alkalmaztuk. Az eseményvezérelt folyamatlánc egy olyan folyamatdiagram típus, amelyet üzleti és munkafolyamatok leírására használnak, mely később alapot adhat a folyamatok fejlesztésére [3]. A rendszer részei: tevékenység, ahol megvalósul az erőforrás felhasználása, esemény, mely a tevékenységet kiváltó elem vagy annak eredménye, valamint a logikai operátorok, melyek az események és a tevékenységek logikai kapcsolatát határozzák meg, amennyiben szükséges. [4]

\section{Folyamatdiagnosztika hibamód és hatáselemzéssel}

A hibamód és hatáselemzés módszertana az 1940-es évek végére tekint vissza, létrehozásának oka a hibák különböző aspektusból való értékelése, így a fenyegetést jelentő problémák számmá alakítása, összehasonlíthatóvá tétele és ezáltal kategorizálhatóságának megkönnyítése volt.[5]

A módszer lényege, hogy minden előforduló hibaokhoz egy értéket rendel (RPN), amely a hiba súlyosságának (Severity, S), gyakoriságának (Occurence, 0) és detektálhatóságának (Detectability ,D) szorzatából áll elő.[6]

Képlete:

$$
R P N=S * O * D
$$

\section{Termék bemutatása}

A cég által összeszerelt termék elsődleges célja a füves területek, mint például futballpályák talajának fellazítása. A gép működése az alábbiak szerint alakul: a vontatmányt egy mezőgazdasági vontató hajtja meg. A gép tüskéi merőlegesen hatolnak be a földbe, majd hegyesszöget bezárva húzódnak ki. Ezáltal mikro repedések képződnek a földben, mely jobb vízelvezetést biztosít a területnek, valamint a gyep gyökerei hosszabbra nyúlnak, és erősebbek is lesznek.

\section{Probléma felvetés és célkitűzés}

Vizsgálatunk helyszínéül egy mezőgazdasági vontatmányokat összeszerelő vállalatot választottunk. Az elemzés első lépéseként megismertük a teljes folyamatot, lemértük az egyes tevékenységek időit, majd 
kialakított szakértői csoporttal végigjártuk az értékteremtés helyét veszteségvadászat céljából. Ezt követően a csoport segítségével rangsoroltuk és csoportosítottuk a feltárt problémákat kvalitatív és kvantitatív minőségjavító eszközök segítségével. A csoportosítást követően javítóintézkedéseket hoztunk, az intézkedések teljes átfutási időcsökkentő hatásait pedig szakértői becslés alapján határoztuk meg.

\section{Jelenlegi folyamat bemutatása}

A folyamat analizálását követően a termelési folyamatot 2 részre bonthatjuk. Az összeszerelő folyamat első szakasza előszerelési tevékenységeket foglal magukban. Ezen állomásokon 6 alkatrész előszerelését végzik, egymást követően, egyszerre nagy darabszámmal. A tevékenységek elvégzésére nincs kijelölt ember, azok végzik, akiknek épp nincs munkájuk, nem tudnak tovább haladni az összeszerelési tevékenységükkel. A folyamat másik szakasza maga a fö összeszerelési folyamat. Itt 15 tevékenységet különböztettük meg egymástól. Egy gépet két operátor szerel össze, ettől csak indokolt esetben térnek el. A folyamatban számos veszteséget fedeztünk fel: állandóan vissza térő hibaként jelentkezett a beszállító által későn leszállított alkatrészek, a nem megfelelő minőségű alkatrészek javításából eredendő időkiesések, állandó várakozás a darura, valamint a szerszámkeresés.

\section{Folyamatdiagnosztika}

A folyamat vizsgálata során 21 tevékenységben találtunk veszteségeket. A tevékenységidőket csoportos bejárással mértük fel, majd eseményvezérelt folyamatlánc diagramot készítettünk a folyamat jobb átláthatósága érdekében. A terepszemlét követően 26 veszteséget azonosítottunk (egy tevékenységhez több veszteség is tartozott), ezeket gyakoriság, detektálhatóság, valamint súlyosság szerint értékeltünk. Az elkészült hibamód és hatáselemzés táblázat értékei alapján ABC-analízissel rangsoroltuk. Ezen felül a hibákat a vállalat szempontjából külső- és belső hibákra bontottuk. A fontos hibák gyökér okainak meghatározása érdekében 5 miért módszert alkalmaztunk. Az azonosított gyökér okokra pedig javítóintézkedéseket hoztunk, hatásukat a teljes átfutási időre szakértői becslés és gyakorlati tesztelések alapján határoztuk meg.

\section{Fejlesztett folyamatok bemutatása}

A folyamatban rejlő veszteségeket két nagy csoportra bontottuk. Az első nagy kategóriát a belső hibák alkották. Ezek a veszteségek a vállalaton belül keletkeznek, amelyekre a vállalat könnyűszerrel hatással lehet. A belső hibák csoportjában az egyik legnagyobb hatással a darura való várakozás volt. A munkagép egy vontatmány előállításában 4 alkalommal vesz részt, a munkaidő közel 30\%-ában működik, így elkerülhetetlen a várakozás. Erre a problémára javaslatunk szerint olyan környezet alakítson ki a vállalat, ahol nem kell 4 alkalommal a daru, valamint a vállalat tulajdonában lévő elektromos targonca is el tudná végezni az összeszerelési folyamat során felmerült forgatási tevékenységeket. Következő jelentéktelennek tűnő, ámbár óriási veszteség a csapágyak kibontásakor képződik. Egy géphez közel 100 darab csapágy kell, mindemellett egy héten hozzávetőleg 25 gépet készítenek. Időn alapuló méréseink szerint csak ezeknek a csapágyak kibontása egy héten egy fő közel 
egy napi munkáját emészti fel. Vizsgálódásunk eredményeként találtunk olyan vállalatot, amely több darab csapágyat tárol vákuumos csomagolásban, így egy mozdulatra akár több csapágyhoz is hozzá lehet férni. Kardinális probléma volt még a szereléshez használt eszközök minőségi és mennyiségi jellemzői. Ezeket minőségi eszközök beszerzésével lehetne orvosolni.

Külső hibának a vállalat által közvetlenül nem befolyásolható problémákat soroltuk. Ilyen volt az alapanyag ellátásban levő csúszások, valamint a nem megfelelő minőségű alapanyagok bevételezése, melyek később, az összeszerelés folyamán utómunkát eredményeznek az operátorok számára. Ezeket a hibákat úgy lehet a legjobban kiküszöbölni, ha a vállalat az alapanyagaiból átgondolt készletszintet tart, így csökkenne a beszállítótól való függősége, és nem kellene a rosszabb minőségű alapanyagokat elfogadni a szállítótól.

\section{Teljes átfutási idők összehasonlítása}

A tanulmányunk utolsó része az összeszerelési folyamatok teljes átfutási időinek összehasonlítása volt. A teljes átfutási idő hozzávetőlegesen 2 munkanap volt. A folyamatdiagnosztika részben ismertetett hibák detektálása után arra a következtetésre jutottunk, hogy a belső veszteségek okainak kiiktatásával a teljes átfutási idő közel 16\%-kal csökkenthető. A külső veszteségek okainak eliminálásával a csökkentés mértéke elérheti a 41\%-ot, valamint ha a vállalat minden általunk feltárt veszteségét kiiktatja az összeszerelési folyamatból, akkor 55\%-os teljes átfutási időcsökkentést érhet el.

\section{Következtetések}

Tanulmányunk fő célja egy mezőgazdasági vontatmányokat összeszerelő vállalat teljes folyamat átfutási idejének csökkentése volt költséghatékony folyamatfejlesztő technikák felhasználásával. A javítóintézkedések hatásvizsgálatát követően arra a következtetésre jutottunk, hogy a folyamat átfutási idejének csökkentése lehetséges. A vállalat a meghozott javító intézkedésekkel élni kívánt, bevezetésük a cikk írásakor folyamatban volt.

\section{Hivatkozások}

[1] P. Horváth, R. Mayer, Konzeption und Entwicklungen, Kostenrechnungspraxis 27 (1993) Sonderheft 2, 16 .

[2] Pokorádi László, Rendszerek és folyamatok modellezése, Campus Kiadó, 25.

[3] J. Mendling, H.A. Reijers, W.M.P. van der Aalst, Seven process modelin guidelines (7PMG), Information and Software Technology 52. (2010) 127-136.

[4] R. Davis, E. Brabander, ARIS Design Platform: Getting Started with BPM, Springer, 105-113.

[5] Michel Baudin, Working with machines, Productivity Press, 290-291.

[6] Automitive Industre Action Group, Potential Failure Mode and Effects Analysis Reference Manual, (1993) 